\title{
Development of Goat Embryos Reconstituted with Somatic Cells: the Effect of Cell-Cycle Coordination between Transferred Nucleus and Recipient Oocytes
}

\author{
Li-Sheng ZHANG ${ }^{1)}$, Man-Xi JIANG ${ }^{1)}$, Zi-Li LEI ${ }^{1)}$, Rui-Chang LI $^{2)}$, Dan SANG ${ }^{2)}$, \\ Qing-Yuan SUN'1) and Da-Yuan CHEN ${ }^{1)}$ \\ ${ }^{1)}$ State Key Laboratory of Reproductive Biology, Institute of Zoology, Chinese Academy of \\ Sciences, Beijing, 100080, ${ }^{2}$ Laboratory of Embryo Engineering, Shengneng Group, City of \\ Linyi, Shandong Province, 250000, China
}

\begin{abstract}
The developmental ability and the nucleus and microtubule dynamics of nuclear transplanted goat embryos derived from in vitro matured oocytes were studied while controlling cellcycle coordination of donor embryonic nuclei and recipient cytoplasts. Three groups of transfers were studied: G0/G1 (after the fibroblast cells grew to 100\% confluence) and G2/M (nocodazole treated) phase fibroblasts transferred to MII cytoplasts (G0/G1 $\rightarrow$ MII and G2/M $\rightarrow$ MII group, respectively), and G0/G1 phase fibroblasts transferred to preactivated cytoplasts, mostly at S-phase, (G0/G1 $\rightarrow$ Pre group) by electrical fusion. The results showed that fusion and developmental ability did not differ between G0/G1 $\rightarrow$ MII and G0/G1 $\rightarrow$ Pre groups. However the developmental rate of embryos in the G0/G1 $\rightarrow$ MII group was significantly higher than that of the G2/M $\rightarrow$ MII group. Most fibroblast nuclei (G0/G1 and G2/M) transferred into MII oocytes underwent premature chromosome condensation (PCC). Normal spindle were only detected in the G0/G1 $\rightarrow$ MII group. In contract, fibroblast nuclei in pre-activated oocytes rarely underwent PCC, but formed a swollen nuclear structure. The data suggest that in vitro matured goat oocytes can support the development of somatic fibroblasts after nuclear transfer, G0/G1 $\rightarrow$ MII and G0/G1 $\rightarrow$ S nuclear transfer might be effective ways for improving the developmental competence of the reconstituted embryos, and that G2/M $\rightarrow$ MII nuclear transfer by electrical fusion (even in $\mathrm{Ca}^{2+}$-free fusion medium) induces abnormal chromosome ploidy.

Key words: Goat, Somatic cell, Nuclear transfer, Cytoplasm
\end{abstract}

(J. Reprod. Dev. 50: 661-666, 2004)

$\mathbf{T}^{\mathrm{T}}$ he cell cycle stages of donor nuclei and recipient cytoplasts are of vital importance for the normal development of embryos reconstructed by nuclear transfer. Two combinations have been proposed as suitable for NT: transfer of G0/G1 nuclei into MII-arrested oocytes, and transfer of G1, $S$, and G2 nuclei into pre-activated oocytes [1]. High maturation promoting factor (MPF) activity of recipient cytoplasm may induce nuclear

Accepted for publication: September 13, 2004

Correspondence: D-Y Chen (e-mail: chendy@panda.ioz.ac.cn) envelope breakdown (NEBD) and premature chromosome condensation (PCC), which seems to be beneficial for nuclear reprogramming $[2,3]$. In contrast, when embryos were reconstructed after the disappearance of MPF activity, no NEBD and no PCC were observed [4]. In this situation, G1 and S-phase nuclei initiated or continued DNA synthesis, respectively, whereas no synthesis was observed in transplanted G2 nuclei. G2/M-phase somatic nuclei were able to support the development of the rat [17]. From these reports we 
hypothesize that one possible factor contributing to the development of reconstructed embryos is the maintenance of correct ploidy [4]. Despite cloned goats having been born for several years, there is little data about the in vitro culture of cloned goat embryos. The present study was conducted to investigate the effects of different cytoplasm and different somatic cell-phase procedures to select the best protocol for subsequent NT development.

\section{Materials and Methods}

\section{Chemicals}

All the chemicals used in the experiment were purchased from Sigma Chemical Company (St. Louis, MO) except for those specifically noted.

\section{In vitro oocyte maturation and selection}

Goat ovaries were collected from a local abattoir and stored at 25-30 C during transportation. When ovaries arrived at the laboratory, they were washed 3 times with warmed Dulbecco PBS (DPBS) and then stored in a water bath at 25-30 C before use. Cumulus oocyte complexes (COCs) were released from the follicles by cutting the ovaries with sharp bistouries in DPBS plus 1\% fetal bovine serum (FBS)(HyClone Laboratories, Inc., Logan, UT) and $10 \mu \mathrm{g} / \mathrm{mL}$ heparin. COCs with more than 4 layers of cumulus cells were selected for in vitro maturation (IVM). Selected COCs were washed three times in in vitro maturation medium (MM199): TCM199 (Gibco, Gaithersburg, Maryland) supplemented with $2 \mathrm{mmol} / \mathrm{L} \mathrm{L}$ glutamine, $10 \mathrm{mmol} / \mathrm{L}$ Hepes, $0.38 \mathrm{mmol} / \mathrm{L}$ pyruvate, $10 \%$ FBS, $1 \mu \mathrm{g} / \mathrm{mL} 17-\beta$ estradiol, $10 \mu \mathrm{g} /$ $\mathrm{mL}$ FSH, $1 \mu \mathrm{g} / \mathrm{mL} \mathrm{LH}$, and $10 \mathrm{ng} / \mathrm{mL}$ epiderminal growth factor (EGF), then cultured for $24 \mathrm{~h}$ in $5 \%$ $\mathrm{CO} 2$ in air at $38.5 \mathrm{C}$. Following in vitro maturation, oocytes were denuded of cumulus cells in $0.5 \%$ hyaluronidase by repeated pipetting, after which oocytes with a first polar body and homogeneous cytoplasm were chosen for nuclear transfer or preactivation.

\section{Cell lines}

Fibroblast cells were obtained from ear skin tissue of an adult female Asian yellow goat. Cell culture and assessment procedures have been described previously [5]. Skin ear tissues were taken, cut into pieces and digested with $0.25 \%$

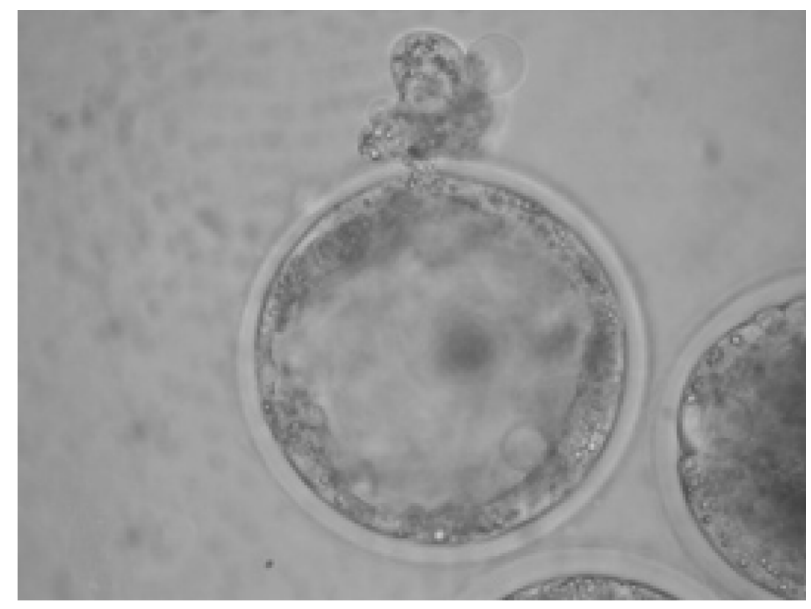

Fig. 1. Blastocyst.

trypsin for $30 \mathrm{~min}$ at $37 \mathrm{C}$. The digested cells and tissues were cultured in DMEM/F12 (Gibco, Gaithersburg, Maryland) (1:1) supplemented with $20 \%$ FBS in a $5 \% \mathrm{CO}_{2}$ in air incubator. Cells were passed when $70 \sim 80 \%$ of them had converged. After reaching 90 100\% confluence, the cells were disaggregated with $0.25 \%(\mathrm{w} / \mathrm{v})$ trypsin and then resuspended in DMEM/F12 (1:1). Cells passed 3 9 generations were used as donors. To get G0/G1 stage cells, the fibroblast cells were disaggregated and the small cells were chosen after reaching 100\% confluence. After reaching 50\% confluence, the cells were incubated with $0.3 \mu \mathrm{g} / \mathrm{mL}$ nocodazole for $12 \mathrm{~h}$ and disaggregated with $0.25 \%(\mathrm{w} / \mathrm{v})$ trypsin, then resuspended in DMEM/F12 (1:1). Large cells (presumed to be G2/M-phase) were chosen for nuclear transfer.

\section{Cytoplast preparation and enucleation}

MII cytoplasm: IVM goat oocytes were enucleated using a micromanipulator (Nikon, Japan) and used as fibroblast recipients in TCM199 supplemented with $15 \%$ FBS and $10 \mathrm{mmol} / \mathrm{L}$ HEPES.

Preactivation cytoplasm: IVM goat oocytes were activated by ionomycin $(5 \mu \mathrm{M})$ and cultured in mCR1aa for 2-3 h. (mCR1aa contains $109.5 \mathrm{mmol}$ / $\mathrm{L} \mathrm{NaCl}, 3.1 \mathrm{mmol} / \mathrm{L} \mathrm{KCl}, 26.2 \mathrm{mmol} / \mathrm{L} \mathrm{NaHCO}_{3}$, $0.4 \mathrm{mmol} / \mathrm{L}$ pyruvate, $5.0 \mathrm{mmol} / \mathrm{L}$ Hemi calcium lactate, $5 \mathrm{mg} / \mathrm{mL}$ BSA, $1.0 \mathrm{mmol} / \mathrm{L} \mathrm{L}$-glutamine, $1.19 \mathrm{mmol} / \mathrm{L} \mathrm{KH}_{2} \mathrm{PO}_{4}, 1.5 \mathrm{mmol} / \mathrm{L} \mathrm{D}$-glucose, 0.80 $\mathrm{mmol} / \mathrm{L} \mathrm{MgCl}_{2}, 2 \%$ essential amino acid, $1 \%$ non essential amino acid and 5\% FBS). The oocytes 
with a second polar body or partially extruding second polar body were chosen.

Metaphase II stage oocytes were enucleated with a $25 \mu \mathrm{m}$ glass pipette by aspirating the first polar body and adjacent cytoplasm surrounding the polar body. Preactivation oocytes were enucleated by removing the first polar body and the surrounding cytoplasm containing the second polar body.

\section{Microinjection}

The microinjection process was as described previously [6]. The pipette was introduced through the same slit in the zona pellucida made during enucleation, and the cell was wedged between the zona and the cytoplast membrane contact for subsequent fusion. The largest cells from the nocodazole-treated population and the smallest cells from the $100 \%$ confluence population, which were assumed to be in G2/M stage and G0/G1 stage, respectively, were chosen as the donor cells.

\section{Activation and embryo culture}

The reconstructed oocytes were equilibrated in mCR1aa for $10 \mathrm{~min}$ and then transferred into a drop of fusion medium (0.27 M mannitol, $0.05 \mathrm{mM}$ $\mathrm{MgSO}_{4}, 0.01 \mathrm{mM}$ HEPES, $0.01 \mathrm{mg} / \mathrm{mL}$ BSA). Electrofusion was performed with two electrical pulses $(100 \mathrm{~V} / \mathrm{mm} \mathrm{DC}$ for $10 \mu \mathrm{s})$ delivered by a Kefa Electro Cell manipulator (Academia Sinica). The fusion was examined $30 \mathrm{~min}$ later. Then the reconstructed oocytes were activated by incubation for $5 \mathrm{~min}$ in $5 \mu \mathrm{mol} / \mathrm{L}$ ionomycin at room temperature. The reconstructed oocytes were transferred to $2 \mathrm{mmol} / \mathrm{L} 6$ dimethylaminopurine(6DMAP) in culture medium, mCR1aa, and cultured for $4 \mathrm{~h}$ at $38 \mathrm{C}$ under $5 \% \mathrm{CO}_{2}$ in air. The culture medium is mCR1aa. Thereafter, groups of 15-20 embryos were carefully washed and transferred to $100 \mu \mathrm{lmCR} 1$ aa under paraffin oil for $36 \mathrm{~h}$. At the 2cell stage, embryos were cultured at $38 \mathrm{C}$ and $5 \%$ $\mathrm{CO}_{2}$ in mCR1aa on a layer of primary murine embryonic fibroblast cells.

\section{Immunocytochemical staining of reconstructed oocytes}

Samples were taken at 1-h intervals after fusion. The method used for immunocytochemical staining has been described previously [7]. Reconstructed oocytes were fixed with $3.7 \%$ (w/v) paraformaldehyde in PBS for $40 \mathrm{~min}$ at room temperature. Fixed oocytes were stored in PBS containing $0.3 \%(\mathrm{w} / \mathrm{v})$ BSA for up to 1 week at $4 \mathrm{C}$. Fixed oocytes were permeabilized by transferring into PBS containing $0.2 \%(\mathrm{w} / \mathrm{v})$ Triton $\mathrm{X}-100$ and $0.1 \%$ Tween-20 and then incubated for $40 \mathrm{~min}$ at room temperature. Then the oocytes were transferred into block solution (PBS containing 1\% BSA) for $40 \mathrm{~min}$ at room temperature. The microtubule was localized with a mouse monoclonal antibody against beta-tubulin, which was diluted in the blocking solution $(1: 200[\mathrm{w} / \mathrm{v}])$ before use. Oocytes were incubated for $40 \mathrm{~min}$ at room temperature, followed by three washes of 5 min each. Oocytes were incubated with fluorescent isothiocyanate-labeled goat-anti-mouse antibody by three washes of $5 \mathrm{~min}$ each. Chromatin was stained with $10 \mu \mathrm{g} / \mathrm{ml}$ of propidium iodide. Finally oocytes were mounted on slides with antifluorescence-fade medium (DABCO). The samples were examined with a laser-scanning confocal microscope (Leica TCS-4D, Bensheim, Germany).

\section{Results}

\section{Cell cycle analysis of donor cells}

The cell cycle stage of ear fibroblast after reaching $100 \%$ and $50 \%$ confluence treated with nocodazole for $12 \mathrm{~h}$ was analyzed using flow cytometry. Analysis of the cell cycle stages in confluent cells are shown in Table 1.

\section{Cell cycle effect on the in vitro development of nuclear transplant embryos}

Fusion and developmental ability did not differ between the G0/G1 $\rightarrow$ MII and G0/ $\mathrm{G} 1 \rightarrow$ preactivation groups. However the developmental rate of G0/G1 $\rightarrow$ MII reconstructed embryos was significantly higher than that of the $\mathrm{G} 2 / \mathrm{M} \rightarrow \mathrm{MII}$ reconstructed group (Table 2 ).

\section{Microtubule patterns and nuclear changes after nuclear transfer}

Microtubule patterns and nucleus changes after transferring fibroblast cells into enucleated MII or preactivated oocyte cytoplasm are shown in Fig. 2. Within $1 \mathrm{~h}$ after the fusion with chrosomeremoved, MII cytoplasm, 79\% (G0/G1 stage phase, $\mathrm{n}=28)$ and $84 \%(\mathrm{G} 2 / \mathrm{M}$ stage phase, $\mathrm{n}=31)$ fibroblast nuclei underwent PCC, whereas nearly all nuclei 
Table 1. Cell cycle of Asian yellow Goat adult fibroblasts incubated with nocodazole and at different confluence in vitro culture

\begin{tabular}{lccc}
\hline & \multicolumn{3}{c}{ Cell cycle phase (Mean $\pm \mathrm{SD})$} \\
\cline { 2 - 4 } & $\mathrm{G}_{0}+\mathrm{G}_{1}(\%)$ & $\mathrm{S}(\%)$ & $\mathrm{G}_{2}+\mathrm{M}(\%)$ \\
\hline $\begin{array}{l}\text { Cells treated with } \\
\text { nocodazole }(0.3 \mu \mathrm{g} / \mathrm{ml}\end{array}$ & $37.75 \pm 1.98^{\mathrm{a}}$ & $10.17 \pm 2.4^{\mathrm{a}}$ & $52.08 \pm 6.45^{\mathrm{a}}$ \\
$\begin{array}{l}50 \% \text { confluence }) \\
\text { Cells growing to }\end{array}$ & $94.64 \pm 0.68^{\mathrm{b}}$ & $1.34 \pm 0.31^{\mathrm{b}}$ & $4.02 \pm 0.25^{\mathrm{b}}$ \\
$100 \%$ confluence & & & \\
\hline
\end{tabular}

Percentages with different superscripts within a column differ significantly $(\mathrm{P}<0.05)$.

Table 2. Fusion and in vitro development of reconstituted goat embryos produced by cell-cycle coordinations between donor nuclei and cytoplasts matured in vitro

\begin{tabular}{lccccc}
\hline Treatment & \multirow{2}{*}{$\begin{array}{c}\text { No. oocytes } \\
\text { surviving enucleation }\end{array}$} & \multicolumn{2}{c}{$\begin{array}{l}\text { No. oocytes } \\
\text { fused }(\%)^{\mathrm{a}}\end{array}$} & \multicolumn{2}{c}{ Development after culture (\%) } \\
\cline { 4 - 6 } & 203 & $118(58.1)^{\mathrm{c}}$ & $63(53.4)^{\mathrm{c}}$ & $23(19.5)^{\mathrm{c}}$ & $8(6.8)^{\mathrm{c}}$ \\
\hline G0/G1 $\rightarrow$ MII & 197 & $99(50.2)^{\mathrm{c}}$ & $49(49.5)^{\mathrm{c}}$ & $18(18.2)^{\mathrm{c}}$ & $6(6.1)^{\mathrm{c}}$ \\
G0/G1 $\rightarrow$ Pre & 89 & $58(65.2)^{\mathrm{c}}$ & $17(29.3)^{\mathrm{d}}$ & $1(1.7)^{\mathrm{d}}$ &
\end{tabular}

a Percentage of the number of the oocytes surviving enucleation. 'Percentage of the number of the oocytes fused.

${ }^{\mathrm{cd}}$ Values with different superscripts differ significantly $(\mathrm{P}<0.05)$. MII: Metaphase II oocytes; Pre: preactivated oocytes.

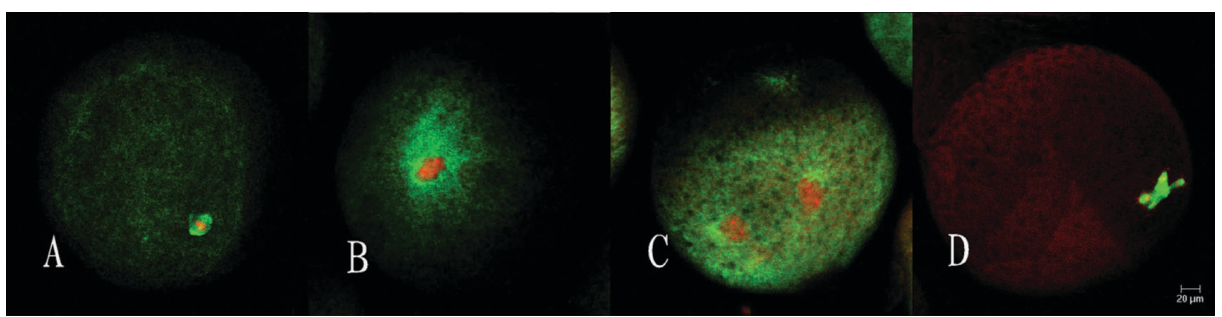

Fig. 2. Laser scanning confocal microscopic images of microtubules and chromatin in reconstructed eggs. Green, microtubule; red, chromatin. A: Well organized spindle and chromosomes aligned on the metaphase plate 4 hours after transferring G0/G1 fibroblast into MII cytoplasm. B, C: A microtubule aster was organized in association with decondensed nuclei in reconstructed eggs under the pre-activated condition. The microtubule aster divided into two at about $8 \mathrm{~h}$ following fusion. D: In G2/M $\rightarrow$ MII nuclear transfer group a multipolar structure was usually formed but no pseudo-polar bodies were extruded.

fused with preactivated oocytes did not show PCC. Meiotic-like microtubular spindles were seen in condensed chromatin in the G0/G1 $\rightarrow$ MII group. And condensed chromosomes were divided into two masses within $4 \mathrm{~h}$ after fusion and developed into two pronucleus-like structures. In the G2/ $\mathrm{M} \rightarrow \mathrm{MII}$ nuclear transfer group, usually multipolar structure were formed but no pseudo-polar bodies were extruded.

A microtubule aster was organized in association with decondensed nuclei in reconstructed oocytes under the pre-activated condition. The microtubule aster divided into two at about $8 \mathrm{~h}$ after fusion. 


\section{Discussion}

The low efficiency of somatic cell cloning is a major obstacle to widespread use of this technology. MPF activity of recipient MII oocytes appears to be important for the reprogramming of nuclei of reconstructed embryos. When enucleated MII oocytes are used as recipient cytoplasts, a series of morphological changes are observed in the donor nucleus after fusion, including the induction of NEBD and PCC followed by nuclear reformation [2]. Previous reports have suggested that the induction of NEBD and PCC is essential for the reprogramming of gene expression, and that it increases the developmental potential of the reconstructed embryos. Wells et al. (1999) demonstrated that exposure of the somatic nucleus to enucleated MII for $4-6 \mathrm{~h}$ before activation resulted in an increased proportion of fused embryos developing into blastocysts [8]. Similar manipulations were also adopted by other groups when nuclei were introduced into MII cytoplast either by electric fusion in cattle $[2,9]$ or by direct nuclear injection in pigs [10].

However, other reports have demonstrated that MPF is not necessary for nuclear reprogramming. Cloned goats [11] and mice [12] have been produced from preactivated oocytes within which MPF activity is low. Production of cloned cattle by using immediate activation has also been reported [13].

In our study, after fusion with chromosomeremoved, MII cytoplast, fibroblast nuclei underwent PCC, whereas nearly all nuclei fused with pre-activated oocytes did not show PCC. However, developmental ability did not differ between the G0/G1 $\rightarrow$ MII and G0/ G1 $\rightarrow$ Preactivation groups, even though there were evident morphological differences in the donor nuclei between the two groups. Therefore, we suppose that MPF activity is not necessary for nuclear reprogramming [11, 12].

The phenomenon that nuclei transferred after the disappearance of MPF activity do not undergo NEBD and DNA synthesis is observed when G1 or $S$ phase nuclei are transferred. Thus the use of activated oocytes to produce cytoplasts removes the occurrence of possible chromosomal damage due to PCC and also, during the first cell cycle, coordinates DNA replication of the donor nuclei in G1, S or G2 phases. Campbell et al. (1994) previously referred to such cytoplasts as the universal recipients [14].

G2/M-stage synchronized donor nuclei might present an advantage over other cell cycle stages used in nuclear transfer, when considering the nucleus-cytoplasm synchronization of karyoplast and cytoplast. When cells in the $\mathrm{M}$ phase are used as donors, reconstructed embryos with a polar body are diploid but embryos without a polar body are tetraploid.

Lai et al. (2001) showed that G2/M stage fibroblast nuclei could direct reconstructed pig embryos to develop to the blastocyst stage [16]. Zhou cloned rats by using M-stage fetal fibroblasts [17]. No reconstructed embryos developed to blastocysts when we transferred the G2/M stage fibroblasts into MII cytoplasts, similar to the results obtained by Alberio et al. The difference is perhaps caused by different micromanipulations. Zhou and Lai used the direct cytoplasm injection method, while Alberio and we used the electric fusion method. In the G2/M $\rightarrow$ MII nuclear transfer group, we did not observe pseudo-polar bodies extruded as reported in rabbit [18] and sheep [19]. One possible reason is that an electric pulse was used to induce the karyoplast/cytoplast fusion before activation. MPF was reduced and the PCC might not be completed before extrusion of PB. Abnormalities of the spindle-like structures were observed such as apolar, monopolar, or tripolar structures. No reconstructed embryos developed to blastocysts when we transferred the G2/M stage fibroblasts into MII cytoplasts, similar to the results obtained by Alberio [15]. The poor developmental ability may be due to aneuploidies of the embryos without extrusion of the PB-like structure [15]. Most of the reconstructed embryos may be tetraploid.

Although we did not carry out chromosome analysis of the reconstructed embryos, our data on chromatin structures suggests that the failure in development may be due to improper chromatin remodeling of mitotic nuclei after NT, resulting in chromosomal abnormalities which are not compatible with normal development.

In conclusion, G0/G1 $\rightarrow$ MII and G0/ G1 $\rightarrow$ preactivation nuclear transfer might be efficient ways to improve the developmental competence of reconstituted goat embryos, while $\mathrm{G} 2 / \mathrm{M} \rightarrow \mathrm{MII}$ nuclear transfer though electrical fusion could decrease embryo development 
probably by inducing abnormal chromosome ploidy.

\section{Acknowledgements}

This research was supported by Climbing Special
Grant 08 from the Ministry of Science and Technology of China and by grant KSCX1-05-01 from the Knowledge Innovation Project of the Chinese Academy of Sciences and a grant from Shengneng Group.

\section{References}

1. Miyoshi K, Rzucidlo SJ, Pratt SL, Stice SL. Improvements in cloning efficiencies may be possible by increasing uniformity in recipient oocytes and donor cells. Biol Reprod 2003; 68: 10791086.

2. Cibelli JB, Stice SL, Golueke PJ, Kane JJ, Jerry J, Blackwell C, Ponce de Leon FA, Robl JM. Cloned transgenic calves produced from nonquiescent fetal fibroblasts. Science 1998; 280 (5367): 1256-1258.

3. Hill JR, Winger QA, Long CR, Looney CR, Thompson JA, Westhusin ME. Development rates of male bovine nuclear transfer embryos derived from adult and fetal cells. Biol Reprod 2000; 62: 11351140.

4. Liu L, Dai Y, Moor RM. Nuclear transfer in sheep embryos: the effect of cell-cycle coordination between nucleus and cytoplasm and the use of in vitro matured oocytes. Mol Reprod Dev 1997; 47: 255-264.

5. Chen DY, Wen DC, Zhang YP, Sun QY, Han ZM, Liu ZH, Shi P, Li JS, Xiangyu JG, Lian L, Kou ZH, Wu YQ, Chen YC, Wang PY, Zhang HM. Interspecies implantation and mitochondria fate of panda-rabbit cloned embryos. Biol Reprod 2002; 67: 637-642.

6. Li GP, Chen DY, Lian L, Han ZM, Zhu ZY, Seidel GE Jr. Rabbit cloning: improved fusion rates using cytochalasin B in the fusion buffer. Mol Reprod Dev 2002; 61: 187-191.

7. Zhu ZY, Chen DY, Li JS, Lian L, Lei L, Han ZM, Sun QY. Rotation of meiotic spindle is controlled by microfilaments in mouse oocytes. Biol Reprod 2003; 68: 943-946.

8. Wells DN, Misica PM, Tervit HR. Production of cloned calves following nuclear transfer with cultured adult mural granulose cells. Biol Reprod 1999; 60: 996-1005.

9. Wells DN, Misica PM, Tervit HR, Vivanco WH. Adult somatic cell nuclear transfer is used to preserve the last surviving cow of the Enderby Island cattle breed. Reprod Fertil Dev. 1998; 10: 369378.

10. Onishi A, Iwamoto M, Akita T, Mikawa S, Takeda K, Awata T, Hanada H, Perry AC. Pig cloning by microinjection of fetal fibroblast nuclei. Science 2000; 289: 1188-1190.

11. Baguisi A, Behboodi E, Melican DT, Pollock JS, Destrempes MM, Cammuso C, Williams JL, Nims SD, Porter CA, Midura P, Palacios MJ, Ayres SL, Denniston RS, Hayes ML, Ziomek CA, Meade HM, Godke RA, Gavin WG, Overstrom EW, Echelard Y. Production of goats by somatic cell nuclear transfer. Nat Biotechnol 1999; 17: 456-461.

12. Gasparrini B, Gao S, Ainslie A, Fletcher J, McGarry M, Ritchie WA, Springbett AJ, Overstrom EW, Wilmut I, De Sousa PA. Cloned mice derived from embryonic stem cell karyoplasts and activated cytoplasts prepared by induced enucleation. Biol Reprod 2003; 68: 1259-1266.

13. Akagi S, Adachi N, Matsukawa K, Kubo M, Takahashi S. Developmental potential of bovine nuclear transfer embryos and postnatal survival rate of cloned calves produced by two different timings of fusion and activation. Mol Reprod Dev 2003; 66: 264-272.

14. Campbell KH, Loi P, Cappai P, Wilmut I. Improved development to blastocyst of ovine nuclear transfer embryos reconstructed during the presumptive S-phase of enucleated activated oocytes. Biol Reprod 1994; 50: 1385-1393.

15. Alberio R, Motlik J, Stojkovic M, Wolf E, Zakhartchenko V. Behavior of M-phase synchronized blastomeres after nuclear transfer in cattle. Mol Reprod Dev 2000; 57: 37-47.

16. Lai L, Tao T, Machaty Z, Kuhholzer B, Sun QY, Park KW, Day BN, Prather RS. Feasibility of producing porcine nuclear transfer embryos by using G2/M-stage fetal fibroblasts as donors. Biol Reprod 2001; 65: 1558-1564.

17. Zhou Q, Renard JP, Le Friec G, Brochard V, Beaujean N, Cherifi Y, Fraichard A, Cozzi J. Generation of fertile cloned rats by regulating oocyte activation. Science 2003; 302 (5648): 1179.

18. Stice SL, Robl JM. Nuclear reprogramming in nuclear transplant rabbit embryos. Biol Reprod 1988; 39: 657-664.

19. Willadsen SM. Nuclear transplantation in sheep embryos. Nature 1986; 320: 63-65. 